\title{
The Italian party system's three functional arenas after the 2018 election: the tsunami after the earthquake
}

\author{
Enrico Calossi \\ Lorenzo Cicchi
}

\section{Introduction}

When electoral results are particularly shocking, the geological metaphor of the earthquake is quite common among political commentators and academics alike. The 2018 Italian election bears no exception as it has been described by many ${ }^{1}$ as a 'political earthquake' whose aftershocks have been perceived elsewhere, especially in Brussels. If the Italian election of 2013, however, has been defined already as an 'electoral earthquake' (Chiaramonte and De Sio 2014), then, how to characterize those of 2018 without the risk of being redundant? What we argue is that the last two Italian elections are part of the same telluric movement whose effects however have had an impact at different times on different arenas. The arenas that we take into account, in this regard, are three: the electoral arena, the parliamentary arena, and the governmental arena, following the theoretical framework proposed by Bardi and Mair (2008). In this sense, if the election of 2013 has been the 'earthquake', that of 2018 can be interpreted as its consequent ferocious 'tsunami', arriving later to complete the destructive process initiated by the antecedent seismic tremor. In fact, the Italian party system, far from settling down after 2013 (when the earthquake has been perceived in the electoral and parliamentary arenas), has suffered a further violent shock in the 2018 election (when the tsunami has concerned the governmental arena as well).

The aim of this article is to assess to what extent this 'change' has been real or only perceived and how much the arenas that compose of the political and the party system have been modified by this 'tsunami' election. In order to do this, we measure the magnitude of this change using a series of indicators for each of the arenas. The time span taken into consideration is the 19482018 period, with a specific focus on the last 25 years, namely since the watershed election of 1994 that completely reshaped the party system after the collapse of the so-called 'First Republic'. The article proceeds as follows: in the first section, we describe the 2018 Italian election, highlighting how much of the (very scarce, due to their newness) literature has focused more on the electoral and parliamentary effects on the party system (Chiaramonte and Emanuele 2018) and on the winners and losers: mainly, the Movimento Cinque Stelle (M5S) and the Lega on one side vis-à-vis the Partito Democratico (PD) on the other (De Sio 2018, Orsina 2018). In the subsequent section, we review the literature on party systems applied to the Italian case, focusing in particular on the polarized pluralism (Sartori 1976), the imperfect bipartitism (Galli 1967), the fragmented bipolarism (D'Alimonte 2005) and the transition towards the new tripolarism (Chiaramonte and Emanuele 2018), and discuss the tripartite theoretical framework of political parties' functional arenas (Bardi and Mair 2008). Then, the following methodological

\footnotetext{
${ }^{1}$ Chiaramonte and Emanuele (2018), but also a variety of political comments by, among others, BBC, Euronews and Votewatch.
} 
paragraph explains how we measure the impact of change within the three arenas, before providing some detailed descriptive statistics of them for the period 1948-2018 (sections 4, 5 and 6). The seventh section discusses the interaction between the party system change in the three arenas, identifying the main differences between the 'critical junctures' (in particular, 1994 and the dyad 2013-2018); the final section draws a number of conclusions and briefly discusses the potential future development of the Italian party system.

\section{The Italian election of 2018}

The 2018 Italian general election was held on 4 March 2018 after the Italian Parliament was dissolved by President Sergio Mattarella at the end of December 2017. Italian voters were called to elect the 630 members of the Chamber of Deputies and the 315 elective members of the Senate of the Republic for the XVIII legislature of the Italian Republic since 1948. The center-right coalition won a plurality of seats in the Chamber of Deputies and in the Senate and Matteo Salvini's Lega emerged as its main component. The anti-establishment M5S led by Luigi Di Maio became the party with the largest number of votes, and the center-left coalition, led by former Prime Minister Matteo Renzi, came third. However, no political group or party won an outright majority, resulting in a political stalemate. After three months of negotiations, an agreement was finally found on 1 June between the M5S and the Lega, whose leaders both became Deputy Prime Ministers in a government led by the M5S-linked non-parliamentarian Giuseppe Conte, a professor of law from the University of Florence, as Prime Minister.

The beginning of something new was immediately recognized and legitimized by the same protagonists of the election. For instance, Luigi Di Maio, leader of the new biggest party, the M5S, and generally perceived as one of the winners of the election (although Matteo Salvini's Lega had increased by four times its votes in respect to the previous election), immediately declared the birth of a new 'Third Republic'.2 The rhetoric of this epochal change is also confirmed by the informal name the M5s and the Lega have chosen for their coalition executive as the 'Government of the Change'. From the general point of view of format and mechanics, the party system resulting from the 2018 election presents a substantially tripolar configuration as it had been in the 2013 election.

However, after the 2013 election, some schiolars spoke of the 'three poles and half' party system (Cotta and Verzichelli 2016), due the importance, during the election of the so-called 'third pole', the three-party coalition led by the incumbent Prime Minister Mario Monti (Pasquino 2013). Actually, it was only the fourth force in terms of votes and seats, definitely far from the centerleft, the center-right and the M5S. This could not be taken for granted after five years, bearing in mind that the 2013 result could have constituted only a temporary deviation from the bipolarism that had been the norm until then. Despite the reconfirmation of a tripolar structure, the party system is once again characterized by some important transformations. The first evidence is that, for the first time, the forces originating from the old 'constitutional arch' are only in the third position, after the center-right coalition and the M5s. Also, the parties that only

\footnotetext{
${ }^{2}$ The M5s had already been the most voted party in the 2013 elections, not including the four 'Italians abroad' constituencies. Despite this, since they were not part of a broader coalition, the M5s did not elect then the highest number of parliamentarians. The PD obtained the bonus of seats, granted by the Porcellum electoral system.
} 
ten years before had almost monopolized the Parliament (PD and Popolo della Libertà), winning together 758 seats out 945 , this time obtained only 34 per cent of parliamentarians.

From a broader perspective, the Italian vote of 2018 has represented a watershed moment, with the greatest success of anti-establishment parties in the panorama of Western Europe since the post-war period. This result is exceptional for at least three reasons. First of all, the success of the $\mathrm{M}_{5} \mathrm{~S}$ is unique in the panorama of Western Europe: among the parties with the best electoral debut (25.6 per cent in 2013), no one had ever managed to do better (in this case, almost +7 percentage points) in its second test. Secondly, Salvini's Lega, capitalizing on the transformation of the old Lega Nord ('Northern League') into a new radical right national League, has also reached an undeniable electoral success, quadrupling the votes and practically reaching the PD levels. Thirdly and on the contrary, the strategy of Renzi's PD, aimed at the conquest of the center and hinged on Europe and civil rights, led to the worst result of the left ${ }^{3}$ in Republican history (De Sio 2018).

However, notwithstanding these first impressions, we aim at empirically evaluating from what to what the Italian party system has evolved. The next section traces the theoretical framework of the three arenas of political party competition, while the following sections describe them in detail.

\section{Party systems and the three functional arenas of political parties}

Party systems are, indeed, something different from 'a mere sum of their parts' (Mair 2006). The literature generally agrees on the basic definition of what a party system is; namely that the existence of a party system as such implies that within a plurality of parties there are interactions between these parties (Sartori 1976). Simply, 'sets of parties', where there are not interactions between parties, are different from 'systems of parties'. Despite the seminal work of Sartori, which aimed to systematize what he defined as a 'plethora' of definitions of party systems, such a term continued to be used in a broad sense.

However, the distinction between a set of parties and a system of parties is not only theoretical. The lack of the 'systematic nature' of a group of parties is not only an analytical element but it takes place concretely when parties (therefore, sets of parties) operate in an environment lacking a systemic identity and hence also systemic constraints. When volatility and fluidity of parties of this environment are very high, they can make the patterned interactions fail to emerge and no real system develops. This was observed to be the case, for example, of the new established democracies in the post-communist Europe (Mair 1997). Sartori, who aimed at classifying all the extant cases of party systems, would have defined it as an 'atomized system'. That insistence of the literature on the classification of party systems was one of the reasons for the persistence of a lack of conceptualization of the constituent elements of a party system. This shortcoming has often made the analysis of the change of party systems difficult and not systematic.

Bardi and Mair (2008) tried to overcome this gap by understanding party systems as multidimensional phenomena, identifying and discussing the implications of three types of division: vertical, horizontal and functional. The vertical division corresponds to the existence of

\footnotetext{
${ }^{3}$ Considering only the main party on the left side of the political spectrum, namely the PD, thus excluding the smaller formation at the left of it (Liberi e Uguali and Potere al Popolo).
} 
some relevant cleavages in society, in addition to the classical left-right axis, which force voters to choose only parties belonging to their national, language or religious constituencies. It is the case of Belgian Francophone parties not allowed to run in the Flemish region and vice versa or the very low probability for a Unionist citizen in Northern Ireland to vote for a Republican party or vice versa. In these cases, thus, two or more party systems coexist in the same polity. This is clear for the electoral arena, while within the parliament forms of interaction can exist.

The horizontal division takes place when different elections are held in the same polity to elect different elective bodies. On such occasions, parties may have different strategies, for example not running in some elections or forging different electoral alliances. This is the case, for example, of local parties in the French-speaking Quebec, which individually run in the provincial elections, but run in the Canadian federal elections jointly within the Bloc Québécois. Or it is also the case of Denmark, where the People's Movement against the European Union only runs in the European elections but does not run in the national and local ones.

However, Bardi and Mair's more refined conceptualization concerns the functional divisions of the party system. This emerges from the existence of different competitive arenas: electoral, parliamentary and governmental. The difference between the electoral party system, on the one hand, and the parliamentary party system, on the other (Bardi 1996) can be very evident: the fundamental logic for parties within the electoral arena is to survive, so to fight on every possible single vote (competition prevails). But this can happen through different strategies, as the logic of competition is strongly influenced by the electoral system. For example, in plurality systems, where everything is decided in a single round, the direction of the competition is centripetal. The fight for votes is concentrated on the median and centrist voters and parties tend to cooperate and to form broad electoral coalitions. On the contrary, where proportional laws exist, the direction of the competition tends to be centrifugal, according to which parties try to reach all the several and dispersed niches of voters. Finally, in majority systems (e.g. France), during the first round parties behave in an all-against-all competition, as they were in a proportional system; in the second round, they usually form alliances, by withdrawing those candidates with fewer chances to win and supporting those with more potentialities. In the parliamentary arena, the coalition formation logic is more diffused (cooperation prevails). In many political system, the electoral formulas do not favor the emergence of a clear (and unique) winner of the elections. Therefore, in the parliamentary system parties work hard to shape ruling coalitions, which could support an executive. For this reason, very often the government arena follows the parliamentary logics, but in some cases, when coalition cabinets are formed, frictions tend to exist when junior parties behave provocatively in order to assert their presence.

This analytical view fits very well with the Italian case, where the different arenas, already during the period up the 1990s, were characterized by quite different logics of competition, such as, for example, that the salient issues in the electoral arena might not be as salient in the parliamentary arena, or vice versa. In the fragmented Italian party system, for example, polarization was much more pronounced in the electoral arena, where parties could take extreme positions in order to respond to the electorate's expectations, rather than in the parliamentary one. On the contrary, since the 1990s, the Italian system has proved to be much more polarized and fragmented in the parliamentary arena rather than in the electoral arena: parties felt the need to regain the visibility they had lost through the centripetal electoral competition induced by the new majoritarian electoral formula. In addition, the interactions between parties could also follow different dynamics within the governmental arena, where parties, which are allied in the electoral and parliamentary arenas, could be in competition even if they are part of the same executive. This 
was, for example, the case of the taut relations between the DS and Margherita ministers in the second Prodi government (2006-2008) and the left-wing exponents of the same cabinet.

Thanks to this theoretical division, it is possible to investigate the extent of 'change' of the Italian party system in the three functional arenas. In addition, particular interest has been given to the impact of new parties in the three different arenas.

\section{Methods to measure party system change}

The object of this analysis is to trace the degree of change of the Italian party system in the three functional arenas (electoral, parliamentary, governmental), with a particular focus on the 2018 election. We do that by looking at two elements of the party system: volatility and innovation. As pointed out by Pedersen, a party system is a system of interaction resulting from inter-party competition, which can be observed at different levels; therefore:

'A concise mapping of party system change would have to cover the levels of parliament and government, the level of the party as an organization, and the level of the electorate. Party system change, then, can be defined as the total set of changes in patterns of interaction and competition at these three levels as well as between them' (Pedersen 1979, 1)

On the one hand, the indexes of volatility that we employ are calculated as follows. For the electoral arena, we rely on the standard index of 'electoral volatility' as initially developed by Pedersen (1979). In more general terms, it calculates the total amount of change of a given characteristic experienced by all individual entities in a closed system. For each entity it calculates the net change of a list between two-time periods, then takes the absolute value of this change and divides the result by the total amount of the characteristics in the system at the first and second time periods. Since most calculations of this nature focus only on the vote share of the full party system, the result of the sum of the absolute value of vote change of all parties is simply divided by two (Casal Bertoa, Deegan-Krause and Haughton 2017). For the parliamentary arena, we employ the same volatility index, where the absolute value of percentage change taken into consideration is however the one of parties' share of parliamentary seats rather than votes ('parliamentary volatility'). ${ }^{4}$ Finally, to calculate the volatility of the third arena, we consider the percentage change, between one cabinet and the subsequent, of the number of ministers (including the Prime Minister) occupied by politicians from a given party.

On the other hand, the indexes of innovation that we employ are calculated as follows. For the electoral arena, it is the sum of the percentages of votes of all new parties in a given election. For the parliamentary arena, it is the sum of the percentages of seats obtained by all new parties in a given election ${ }^{5}$. For the governmental arena, it is the percentage of ministers (including the post of Prime Minister) occupied by politicians from new parties. Then, what exactly a 'new party' is? The literature has long debated on this question (Emanuele and Chiaramonte 2016). Starting from the most inclusive definition, Harmel and Robertson (1985) consider a relabeling or joint lists as a sufficient condition to consider the party a truly new entity. Other scholars consider necessary at least a merger (Birch 2003, Powell and Tucker 2014, Bolleyer 2013) or a split (Mainwaring, Gervasoni, and España-Najera 2016, Hug 2001, Tavits 2006, Zons 2015, Barnea and

\footnotetext{
${ }^{4}$ The indexes of electoral and parliamentary volatility take into consideration votes and seats of the Chamber of the Deputies alone.

${ }^{5}$ For these two indicators, we focus only on votes and seats in the Chamber of Deputies.
} 
Rahat 2011) to talk about new parties. Other more restrictive definitions include the presence of a start-up organization (Bartolini and Mair 1990, Chiaramonte and Emanuele 2015) or even new personnel (Sikk 2005, Marinova 2015) as a defining element of new parties. In this work, with the help of the relatively small sample, we combine a rather restrictive approach with an ad-hoc interpretation in case of splits. First of all, we do not consider as new parties those that have changed (even significantly) their names but have kept the same political personnel and similar ideology. Also, similarly to Emanuele and Chiaramonte (2016), we consider new parties those that for the first time in an election obtained more than 1 per cent of votes. For instance, we consider the Lega Nord as a new party only in 1992, when it obtained 8 per cent of votes, although the predecessor Lega Lombarda (with a very similar electoral logo, a similar ideology and the same leader, Umberto Bossi) was already present in the 1987 election, but had received less than 1 per cent of votes. When existing parties merge, such as Alleanza Nazionale (AN) and Forza Italia (FI) within the Popolo delle Libertà (PDL) in 2008, or DS and Margherita within the Partito Democratico (PD) in 2007, we do not consider these actors as new parties because of the clear continuity in terms of leadership, ideology and structures. In case of split, the situation is more complex. Generally, we do not consider as a new party the largest of those originating from the old one. In 1991, after the transformation of the Partito Comunista Italiano (PCI) in the PDS and the consequent split of the Partito di Rifondazione Comunista (PRC), we consider only the latter as a new party. An exceptional case is represented by the split of the Partito Popolare Italiano (PPI) in 1995. A splitting fraction was allowed to keep the name but was forced to change the electoral logo; the other component, led by the secretary general of the party Rocco Buttiglione, was allowed to keep the logo - the same of the ancient Democrazia Cristiana (DC) - but was required to rename into Cristiano Democratici Uniti (CDU). In this case, we do not consider either as a new party.

\section{The electoral arena}

Our analysis starts from the electoral arena. In fact, 'even if elections are far from always being decisive events, they are still the best available vantage point for a study of change, because change will either be a result of elections, or elections will register any change which may occur in the party system' (Pedersen 1979, 2). Table 1 shows the evolution of the Italian party system in terms of electoral volatility.

\section{$\leftarrow$ Table 1 about here $\rightarrow$}

The result of the heavily controversial ${ }^{6} 1953$ election gave birth to a political balance that would last for around 40 years. The DC was at the core of a centrist coalition (with the Partito Liberale, PLI, the Partito Social Democratico, PSDI, and the Partito Repubblicano, PRI) opposed by a strong left opposition (with the Partito Comunista, $\mathrm{PCl}$, in a stronger position than the Partito Socialista, PSI) and a weaker right-wing opposition (the Partito Nazionale Monarchico, PNM, and the

\footnotetext{
${ }^{6}$ Due to the super bonus of two thirds of seats, introduced by the DC-led government prior to the elections, to the winning coalition scoring at least 50 per cent of the votes. The centrist bloc however scored only 55,038 votes below the necessary threshold, so the normal proportional allocation of seats applied. In 1954 this provision was then repealed.
} 
Movimento Sociale Italiano, MSI). This set-up of the party system remained very stable until 1992. After the election of 1953 the electoral volatility reached 12.4 per cent, due to the strong recover of the left parties, but it never reached again 10 per cent before the 1990s' party system reshuffling. The electoral fluxes were characterized by the continuous growth of the $\mathrm{PCl}$, until 1976, the erosion of votes for the DC (until 1983) and PSI (until 1976), and the dissolution of the Monarchists. Already in 1967 Giorgio Galli could coin the definition of 'imperfect bipartitism' between the $\mathrm{DC}$ and the $\mathrm{PCl}$, even if the gap was yet of 13 per cent: only in 1983 the distance reached the minimum: 32.9 per cent vs 29.9.

As it can be seen from table 2, during the first twenty years the impact of new parties was very limited; in the 1970 s and the 1980s, however, the party system gave the first sign of instability, with several new parties appearing. But the first real symptom of a crisis, anticipating the 199293 collapse, happened in the 1992 election. For the first time volatility overcame 10 per cent, reaching 18.7 per cent. The three new parties, La Rete (1.86 per cent), PRC $^{7}$ (5.62 per cent) and the Lega Nord (LN, 8.65 per cent) jointly scored 16.1 per cent of votes. Of these three new parties the success of the latter was considered as a worrying alarm by many commentators (Biorcio 1997). In fact, the LN placed itself outside of the classical left-right divide, which had characterized the Italian party system until then, and posed strong and populist critics towards the 'system of parties'. In conclusion, it was the first time that a new party, other than the marginalized MSI and the already dissolved monarchists, scored so well being outside the Constitutional Arch.

\section{$\leftarrow$ Table 2 about here $\rightarrow$}

The legislature of the 1992 had a short life. The Mani Pulite judicial investigation and the approval of the mixed-majoritarian electoral system (Mattarellum) caused the complete reshape of the Italian party system. The electoral volatility skyrocketed at 40.9 per cent and additional three new parties entered the scene: Alleanza Democratica (1.2 per cent), Patto Segni (4.7 per cent) and above all Silvio Berlusconi's Forza Italia, which became immediately the biggest party with 21 per cent of votes. In sum, these three new parties received 26.9 per cent, a level never reached before. These changes induced many to speak of the emergence of a so-called 'Second Republic', even if, except for the electoral system, all other constitutional aspects of the Italian democracy had maintained the same framework of the previous 40 years.

The system seemed to have reached a limited stability in the following elections. In the four elections between 1996 and 2008, volatility only once reached 22.8 per cent (in 2001) and in 2006 was down to the levels of 40 years earlier (8.6 per cent). However, this period was characterized by the birth of other new parties: Rinnovamento Italiano in 1996, Italia dei Valori, Democrazia Europea and the Partito dei Comunisti Italiani in 2001, the UDEUR in 2006, and finally la Destra and the Movimento per l'Autonomia in 2008. However, the overall shares of votes obtained by these

\footnotetext{
${ }^{7}$ When the PCI transformed into the PDS most of the leadership joined the new party, which kept within its new electoral symbol the ancient PCI logo (Ignazi 1992). On the contrary, the PRC was led by a minor fraction of the former leadership and the electoral symbol, although it kept the classical hammer and sickle in a prominent position, was completely different from that of the PCI (Bertolino 2004). Therefore, the PDS can be considered as the PCI 'in a new fashion', while only the PRC can be considered as a new party.
} 
new parties were much lower than the levels of the 1992-1994 period. These indicators appeared to confirm that the party system, at least in the electoral arena, had reached a stability. This seemed validated also by the fact that almost the total of the votes was concentrated in only two coalitions in 2006 and that the votes received by the two biggest parties in 2008, the PDL and the PD, reached 70.5 per cent, the second highest score after 73.1 per cent of 1976.

This new equilibrium, however, demonstrated its fragility in the 2013 election. The 'electoral earthquake' was perceived both as very high volatility (40.3 per cent, at the same level of 1994) and high number of new parties, 5: Fare per Fermare il Declino (1.1 per cent), Fratelli d'Italia (1.96 per cent), Sinistra Ecologia e Libertà (3.20 per cent), the self-defined 'third pole' Scelta Civica (8.3 per cent) and the effective third force of that election, and biggest party in the national territory, the M5S (25.6 per cent). Overall, 40.2 per cent of votes went to parties that did not exist five years before. From an electoral point of view, other new parties entered the scene in 2018, +Europa, Liberi e Uguali and Potere al Popolo, but on the whole the amount of their votes was only about 7 per cent. On the contrary, volatility reached the third highest level indicating that the new electoral context emerged from the 2013 general elections was again an instable one.

\section{The parliamentary Arena}

For what concerns the evolution of the format and of the dynamics of the parliamentary arena in comparison with those of the electoral arena, it is noteworthy that 'institutional factors may also be responsible for creating different conditions of competition in the two arenas' (Bardi and Mair 2008, 157-8). The electoral system is one of the most important aspects that shape the differences and similarities between party systems. As for the format of the party systems in the two arenas, it is easy to understand that the proportional formula imposed a strong similarity between the two. The elections of 1953 and 1992 were those with the highest electoral volatility and subsequently those with the highest parliamentary volatility. The same happened for party innovation, which was almost non-existing in both the arenas until 1992.

\section{$\leftarrow$ Table 3 about here $\rightarrow$}

As for the dynamics of competition, the analysis is more complex. The proportional system facilitated the establishment of a 'polarized pluralism' (Sartori 1966) in the electoral area, characterized by a centrifugal competition. However, parties that during the elections proposed different policy solutions and seemed to represent incompatible Weltanschauungen were able to negotiate and find agreements in the parliamentary arena. Even if the period 1948-1992 was characterized by the stability of the ruling coalition, this did not prevent the formation of a consensual climate on many general issues, at least amongst the parties of the "Constitutional Arch', which allowed some commentators to define the Italian party system as 'bargained pluralism' (Hine 1993). Sartori's and Hine's definitions seem to be at odds, but that contradiction is only apparent: as the Italian party system was polarized in the electoral arena and consensual in the parliamentary one. Obviously, the main reason is that the electoral arena has never been really competitive. The DC occupied constantly the center of the system having two incompatible oppositions on the left and the right. The inclusive strategy of the 'centrism', with PSLI, the PLI and PRI in the ruling coalition, always characterized the DC's behavior. The consequence was a continuous enlargement of the government coalition, which passed from the centrist formula of 
the 1950s, to the center-left of the 1960 s and 1970 s and to the 'pentapartito' in the 1980s. The consensual imperative of the parliamentary arena is not only exemplified by the progressive expansion of the governmental coalition but was also characterized by other two processes. The first was the recurrence of the 'external support' from parties formally located at the opposition, the Monarchists and the neo-Fascists in the 1950 s and the Communists in the 1970s. The second, and more frequent, was the sharing of public offices and state resources among parties. This process, which touched many sectors of society, from the management of the national health service to the distribution of the top-level positions in state institutions, from the introduction of public funding for political parties (Pizzimenti and Ignazi 2011) to the 'occupation' of the municipalized companies, was completely in line with the conceptualization of the 'cartel party' (Katz and Mair 1995, Bardi 2006).

Things changed abruptly in 1994, when the approval of the new mixed-majoritarian electoral system and the judicial investigations on the ruling parties provoked a dramatic impact on the format and dynamics of the party system in the two arenas. The new electoral law facilitated the structuring of the electoral supply into three different blocs and new parties (Forza Italia overall) emerged. From that time on two tendencies can be measured. The first one is the divergence between the electoral and parliamentary volatilities, with the latter constantly higher. This effect is clearly due to the distortive effect of the new mixed-majoritarian system. The Mattarellum (which adopted the first-past-the-post formula for three-fourth of the seats) assured higher volatility in the parliamentary arena: 46 percent vs 40 in 1994, 21 vs 15 in 1996, 23 vs 22 in 2001. These gaps were almost of the same degree in the three elections run with the Porcellum system (which granted 340 seats to the coalition or list with the highest number of votes): parliamentary volatility was 13 percent vs 8 per cent of the electoral one in 2006, 24 vs 16 in 2008 and 44 vs 40 in 2013. The second process was the great parliamentary strength of the center-left and centerright, always able to occupy more than 90 per seats, with peaks in 2001 when only 11 seats were left to third parties and in 2006 when the two coalitions occupied the entire Chamber of Deputies. In 2008, this tendency to bipolarization seemed to lead even to a bipartization of the system.

\section{$\leftarrow$ Table 4 about here $\rightarrow$}

This tendency came to a complete halt in 2013. The change was immediately observed for what concerns the electoral supply: three coalitions running in the elections (center-right, center-left and center) and at least three alone-standing lists with the hope to obtain seats (M5S, Fare per fermare il Declino, and Rivoluzione Civile). Also in this case, high volatility in the electoral arena is reflected in a higher volatility in the parliamentary one (44 percent to 40), but the party innovation was not as strong: electoral innovation was 40 percent but it was only 26 percent in the parliamentary arena. This happened because the PD, an existing party, secured the bonus, leaving fewer seats to the new parties. For the 2018 election, the recently introduced 'mixed' electoral formula, the Rosatellum, continued to produce significant disproportional effects. The parliamentary volatility was high also in this election, 42 per cent, and higher than the electoral one. This demonstrates that the 2013 election was far from shaping a new stable party system in the parliamentary arena. On the contrary, the innovation caused by successful new parties was very limited: only 2.6 percent of seats was conquered by new lists (see table 4 ). 


\section{The governmental arena}

The analysis of governmental volatility and innovation shows interesting results. Table 1 presents the scores of governmental volatility for the 65 governments of the Italian Republican period, together with additional information on the government (party of the Prime Minister, cabinet size and share of ministers between technocratic or independent ministers, new parties and established parties). Figure 1 shows graphically the trend of governmental volatility, and table 6 presents detailed information on governmental innovation.

\section{$\leftarrow$ Table 5 about here $\rightarrow$}

First of all, it is worth noting that until 1994 total volatility (the change in ministers representing different parties) was constantly below 50 percent: the majority of ministers were always DC members. Volatility was due to the change of quotas between the parties of the government's coalition: four parties of the 'centrism' formula (other than the DC, also PLI, PSDI and PRI) between 1948 and 1963, and four of the 'center-left' experience (with the PSI replacing the PLI in the governmental coalition), and the five of the 'pentapartito' (DC, PSI, PLI, PSDI and PRI) between 1981 and 1993. Volatility in the governmental arena did not reflect electoral or parliamentary volatilities nor the transition from one governmental formula to another, but rather the relationships between parliamentary parties. The transition phases where characterized by 'monochrome' DC-led or centrist executives with the external support (without direct ministerial participation) of parties officially in the opposition: this was the case of the MSI and Monarchists' support to the Tambroni executive in 1960, the socialist support to the Fanfani IV executive in 1962 and the communist support to the Andreotti III executive in 1976. These experiments were clearly attempts to enlarge the governmental coalition at a later stage. This happened with the entry of the PSI in the first 'center-left' cabinet in 1963, which is also the only case of innovation that happened in the governmental arena before 1993. Noteworthy is also that from 1948 until 1981, all the Prime Ministers were Christian Democrats. This informal rule was broken in 1981, when the Republican Giovanni Spadolini became Prime Minister and again in 1983, when it was the time for the Socialist leader Bettino Craxi (Ignazi 1997).

\section{$\leftarrow$ Figure 1 about here $\rightarrow$}

In 1992, following Mani Pulite, it became necessary to form a new executive, led by a nonpolitician and supported by the largest possible coalition. For that reason, in the Ciampi cabinet there were significant changes. For the first time two new parties, the PDS and the Greens, obtained ministerial offices: four ministers out of 28 belonged to new parties. However, this historical event did not have practical consequences, because already the day after the government had sworn in, 4 May 1993, the PDS and the Greens withdrew their ministers from the cabinet, as a form of protest because the Chamber of Deputies voted against the opening of a judicial investigation on Bettino Craxi. 
The watershed elections of 1994 show striking results for both indicators. For the first time, volatility reached values higher than 50 per cent; governmental innovation is even more pronounced and reached the highest peak ever (76.9 per cent), because the three main parties forming the governing coalition had never been in power before (FI, LN and AN). Volatility was very high also in 1995, as this was a non-partisan government vis-à-vis the almost complete absence of technocratic ministers of the previous cabinet (McDonnell and Valbruzzi 2014). As figure 1 shows, volatility keeps growing during the late 1990s - early 2010 s period, consistently with the alternation of power between center-left and center-right. If we ignore the intralegislature government reshufflings, ${ }^{8}$ volatility shows continuously growing results (Prodi I: 79.9; Berlusconi I: 79.67; 2006: Prodi II: 82.1; Berlusconi II: 94.1) until Letta in 2013, when it falls again under 90 per cent (86.2).

The 2018 Conte government, for the first time in Republican history, shows total volatility (100 per cent). In fact, before, every executive had at least some ministers belonging to parties that were in power in the previous cabinet ${ }^{9}$; in 2018, there is a total disjunction with the past. If volatility is extraordinarily high, innovation, on the other hand, is relatively low, as the yellowgreen cabinet has a number of technocratic ministers, and the 'nationalized' Lega had been in power already in 1994, 2001 and 2008. Therefore, only the eight ministers from the M5S count for the governmental innovation.

\section{Comparative Analysis of the Three Functional Arenas}

So far, we have analyzed the innovation and volatility of the Italian party system separately for the three functional arenas. However, a number of insights comes from comparing these two characteristics in the three arenas together. As shown by figure 1, there is a clear-cut division in the three arenas between the pre- and post-1994 political system. In the long period between 1953 and 1993, electoral and parliamentary volatility never exceeds 10 per cent, and consistently with the pure proportional system, these two indicators score almost identical results. Governmental volatility, on the other hand, has a more undulating trend, showing high peaks and low downs, but never reaching 50 per cent.

\section{$\leftarrow$ Figure 2 about here $\rightarrow$}

The election of 1992 showed some preliminary signs of disruption. Both electoral and parliamentary volatility show - at that time - the highest value since 1953 , close to 20 per cent, while governmental volatility is still low. After 1994 then, electoral and parliamentary volatility show a much different and wavier pattern: it reaches peaks over 40 per cent, but also shrinks back to levels close to 10 per cent (in 2006). Yet again, the biggest pre- and post-1994 difference lies in the governmental volatility, never above 50 per cent first, and then always over 75 per cent. It is also worth noting how, using mixed proportional-majoritarian systems (Mattarellum

\footnotetext{
${ }^{8}$ Also with the technocrat-led governments Dini and Monti, formed after political governments, volatility is higher than 50 per cent.

${ }^{9}$ Most notably, politicians from centrist parties, legacy of the DC-centered cabinets.
} 
and Rosatellum) and the majority bonus proportional (Porcellum), the results of electoral and parliamentary volatility tend to diverge much more than with the previous proportional system. The current Rosatellum, in particular, is the electoral system that so far has led to the biggest discrepancy between the two volatilities, around 13 per cent. ${ }^{10}$ This is another element of novelty of the election of 2018, a moment of substantial halt in respect to the previous setting not only for the already mentioned full governmental volatility.

\section{$\leftarrow$ Figure 3 about here $\rightarrow$}

Additional insights come from the comparative analysis of innovation in the three arenas. Here, more than volatility, we can appreciate how 1994 and the two-stage process 2013-2018 were indeed moments of epochal change in the Italian party system. If we exclude these occasions, the index of innovation in all the three arenas never exceeds 12 per cent. In 1994, the result of new parties among the electorate and in the parliament (notably FI), led to a government where 77 per cent of ministers belonged to new parties. Between 1996 and 2008, the years of bipolarism, these indexes go back to moderate levels. In 2013 the indexes of electoral and parliamentary innovation marks the first stage of the political 'earthquake' (Chiaramonte and Emanuele 2014). Mainly because of the exploit of the populist M5S, ${ }^{11}$ electoral innovation of 2013 is, in fact, the highest of all Italian Republican history (40 per cent), way higher than the second highest, reached in 1994 (25 per cent). However, due to bonus of the Porcellum electoral law, favoring the winning center-left coalition, parliamentary innovation was limited to about 25 per cent, approximately the same score of 1994. If these effects, then, were not perceived in the governmental arena, with the formation of the continuity-oriented Letta cabinet characterized by extremely low governmental innovation, they would concern this arena too five years later, when the 'tsunami' was felt in all its strength. Despite the Lega having already been in power, and the surprisingly high number of technocratic ministers, the Conte government is, indeed, the second most innovative government since 1953. Therefore, if 1994 was the single moment of passage from one party system to another, in the $2010 \mathrm{~s}$ the road towards a new system has taken five years, instead of happening in a single moment.

\section{Conclusions}

This study has analyzed what the Italian party system has changed to after the 2018 election. The impression of a significant change is widespread; this article has aimed at empirically assessing the degree of this change. Thanks to the historical analysis of the indexes of party volatility and innovation in the electoral, parliamentary and governmental arenas, we have recognized a significant stability for the party system in all the arenas in the period 1953-1992. The seismic sensors of the Italian party system went haywire in 1994, when both the indicators skyrocketed at the same moment in the three arenas. Something different has happened in the 2018 general

\footnotetext{
${ }^{10}$ In 2018, the parliamentary volatility scores about 29 per cent while the electoral volatility scores about 42 per cent.

${ }^{11}$ Not only M5S, however: 2013 was also the election where the highest number of new parties emerged, 5 in total: in addition to M5S, also Sinistra, Ecologia e Libertà, Fratelli d'Italia, Scelta Civica and Fare per Fermare il Declino reached at least 1 per cent of the votes.
} 
elections. In fact, in this occasion, the volatility index reached new maximal levels only in the governmental area, as volatility in the other two arenas is lower than 5 years earlier. More important, the innovation index of the 2018 election, very high for the governmental arena, is relatively low for the electoral and the parliamentary ones. For this indicator too, the crucial moment of change has been the 2013 election.

Therefore, at least two differences can be registered between the two reshaping events of the Italian party system. The first difference is that the change of the 1990s happened in only one moment, the 1994 election, in which the alliances of political parties (the forging of the electoral blocs) and the modification of the electoral system, rather than the voting behavior of citizens, had an impact on the transformation of the party system in all the three functional arenas. On the contrary, the change of 2013 was mostly a consequence of the voters' strategies, being the electoral formula and the electoral alliances the same. The change in voting behavior, however, was enough to modify the electoral and the parliamentary faces of the Italian party system. But the variation in the governmental arena happened only in a second time, when a new change in the voters' behavior, and not of the alliances' strategies, run in parallel with the introduction of a new electoral formula. Only in 2018 therefore, i.e. after two elections, we can claim that the party system has changed as it had happened in 1994. For the first transformation of the party system, only one single moment was enough; for the second, two different occasions were necessary. However, we do not know yet if this could be interpreted as the passage towards a new 'Third Republic', as it has been already hypothesized (or auspicated) by some commentators. After all, it is still questionable whether the 1993 events truly embodied the transition from the 'First' to the 'Second Republic'. In any case, only after the next election, if volatility and innovation in the three arenas will reduce substantially, then we could affirm that the Italian Republic has reached a new party system. A system that would then be fully consolidated in all the three different functional arenas, and therefore apt for being considered the 'third party system' of the Italian Republic, rather than a 'Third Republic' in itself. 


\section{Bibliography}

Bardi, L. 1996. “Change in the Italian Party System”, Res Publica 38: 279-94.

Bardi, L. 2002. "Italian Parties: Change and Functionality", in Paul Webb, David Farrell and Ian Holliday (eds.) Political Parties in Advanced Industrial Democracies, pp. 46-76. Oxford: Oxford University Press.

Bardi, L. 2006 (ed). Partiti e sistemi di partito, Bologna: Il Mulino.

Bardi, L. and Mair, P. 2008. "The Parameters of Party Systems", Party Politics Vol 14, Issue 2, pp. $147-166$.

Barnea, S. and Rahat, G. 2011. "Out with the old, in with the 'new': what constitutes a new party?", Party Politics 17(3): 303-320.

Bartolini, S. and Mair, P. 1990. Identity, Competition and Electoral Availability: The Stabilisation of European Electorates 1885-1985. Cambridge: Cambridge University Press.

Bertolino, S. 2004. Rifondazione comunista: storia e organizzazione, Bologna: Il Mulino.

Biorcio, R. 1997. La Padania Promessa. La storia, le idee e la logica d'azione della Lega Nord, DOVE: II Saggiatore

Birch, S. 2003. Electoral Systems and Political Transformation in Post-Communist Europe. Basingstoke: Palgrave Macmillan.

Bolleyer, N. 2013. New Parties in Old Party Systems: Persistence and Decline in Seventeen Democracies. Oxford: Oxford University Press.

Casal Bértoa F., Deegan-Krause K. and Haughton T. 2017. "The volatility of volatility: Measuring change in party vte shares”, Electoral Studies, Volume 50, 2017, Pages 142-156,

Chiaramonte, A. and De Sio, L. 2014. (eds.), Terremoto elettorale. Le elezioni politiche del 2013, Bologna, II Mulino.

Chiaramonte, A. and Emanuele, V. 2015. "Party system volatility, regeneration and deinstitutionalization in Western Europe (1945-2015)". Party Politics. Epub ahead of print 25 August 2015.

Chiaramonte, A. and Emanuele, V. 2018. "L'onda sismica non si arresta. Il mutamento del sistema partitico italiano dopo le elezioni 2018", CISE working paper

Chiaramonte, A. and Emanuele, V. 2014. "Bipolarismo Addio? II Sistema Partitico tra Cambiamento e De-Istituzionalizzazione", in A. Chiaramonte and L. De Sio (eds.), Terremoto elettorale. Le elezioni politiche del 2013, Bologna, II Mulino, pp. 233-262.

Cotta, M. and Verzichelli, L. 2016. Il Sistema Politico Italiano. Bologna: II Mulino.

D’Alimonte, R. 2005. “Italy: A Case of Fragmented Bipolarism”, in G. M. \& M. P. (eds.), The Politics of Electoral Systems (pp. 253-276). Oxford: Oxford University Press.

D'Alimonte, R. and Chiaramonte, A. 2007. Proporzionale ma non solo: le elezioni politiche del 2006, Bologna: II Mulino.

De Sio, L. 2018. “Il Ritorno del Voto di Classe, ma al Contrario: ovvero, se il PD è il Partito delle Elite", CISE working paper, 
Galli, G. 1967. II Bipartitismo Imperfetto. Bologna: II Mulino.

Hine, D. 1993. Governing Italy: The Politics of Bargained Pluralism. Oxford: Oxford University Press.

Hug, S. 2001. Altering Party Systems: Strategic Behavior and the Emergence of New Political Parties in Western Democracies. Ann Arbor: University of Michigan Press.

Ignazi, P. 1992. Dal PCl al PDS, Bologna: Il Mulino.

Ignazi, P. 1997. I partiti italiani, Bologna: II Mulino.

Katz, R. S. and Mair, P. 1995. "Changing Models of Party Organization and Party Democracy: the emergence of the cartel party”, Party Politics, Vol. 1, No. 1, p 5-31.

Mainwaring, S., Gervasoni, C. and España-Najera, A. 2016. "Extra- and Within-system electoral volatility. Party Politics”. Online Appendix. Epub ahead of print 11 January 2016.

Mair, P. 1997. Party System Change: approaches and interpretations, Oxford University Press, Oxford.

Mair, P. 2006. "Ruling the Void: The Hollowing of Western Democracy", New Left Review, 2006, 42, 25-51.

Mair, P. 2007. "Party systems and alternation in government, 1950-2000: innovation and institutionalization", in: Gloppen, S., Rakner, L. (eds.), Globalisation and Democratisation: Challenges for Political Parties. Fagbokforlaget, Bergen, pp. 135-153.

Marinova, D. M. 2015. "A new approach to estimating electoral instability in parties", Political Science Research and Methods 3(2): 265-280.

McDonnell, D., \& Valbruzzi, M. 2014. "Defining and classifying technocrat-led and technocratic governments", European Journal of Political Research, 53(4), 654-671.

Orsina, G. 2018." La sorprendente cavalcata di Salvini spiegata con gli attrezzi dello storico", LUISS Open editorial, April 26th 2018,

Pasquino, G., 2013. Finale di partita. Tramonto di una Repubblica. Milano: Egea.

Pedersen, M. N. 1979. 'The dynamics of European party systems: changing patterns of electoral volatility', European Journal of Political Research, 7, pp. 1-26.

Pizzimenti, E. and Ignazi, P. 2011. "Party Financing and Party Organisational Change: the Italian Case." Rivista italiana di scienza politica 41.2 (2011): 199-236.

Powell, E. N. and Tucker, J. A. 2014. "Revisiting electoral volatility in post-communist countries: new data, new results and new approaches", British Journal of Political Science 44(1): 123-147.

Sartori, G. 1966. "European Political Parties: The Case of Polarized Pluralism", in Joseph LaPalombara and Myron Weiner (eds) Political Parties and Political Development. Princeton: Princeton University Press.

Sartori, G. 1976. Parties and Party Systems. Cambridge: Cambridge University Press.

Sartori, G. 1966. "European Political Parties: The Case of Polarized Pluralism”, in Joseph LaPalombara and Myron Weiner (eds) Political Parties and Political Development, pp. 137-76. Princeton, NJ: Princeton University Press.

Sikk, A. 2005. "How unstable? Volatility and the genuinely new parties in Eastern Europe", European Journal of Political Research 44: 391-412. 
Tavits, M. 2006. "Party system change. Testing a model of new party entry", Party Politics 12(1): 99-119.

Zons, G. 2015. "The influence of programmatic diversity on the formation of new political parties", Party Politics 21(6): 919-929. 
Table 1. Party and bloc electoral volatility, 1953-2018

\begin{tabular}{ccc} 
Electoral cycle (T1-T2) & Party volatility at T2 & Bloc volatility at T2 \\
\hline $1948-1953$ & $12.4 \%$ & $\mathrm{n} / \mathrm{a}$ \\
$1953-1958$ & $6.5 \%$ & $\mathrm{n} / \mathrm{a}$ \\
$1958-1963$ & $7.7 \%$ & $\mathrm{n} / \mathrm{a}$ \\
$1963-1968$ & $7.6 \%$ & $\mathrm{n} / \mathrm{a}$ \\
$1968-1972$ & $5.9 \%$ & $\mathrm{n} / \mathrm{a}$ \\
$1972-1976$ & $9.5 \%$ & $\mathrm{n} / \mathrm{a}$ \\
$1976-1979$ & $5.5 \%$ & $\mathrm{n} / \mathrm{a}$ \\
$1979-1983$ & $8.5 \%$ & $\mathrm{n} / \mathrm{a}$ \\
$1983-1987$ & $8.1 \%$ & $\mathrm{n} / \mathrm{a}$ \\
$1987-1992$ & $18.7 \%$ & $\mathrm{n} / \mathrm{a}$ \\
$1992-1994$ & $40.9 \%$ & $\mathrm{n} / \mathrm{a}$ \\
$1994-1996$ & $15.8 \%$ & $\mathbf{2 2 . 6 \%}$ \\
$1996-2001$ & $22.8 \%$ & $\mathbf{7 . 7 \%}$ \\
$2001-2006$ & $8.9 \%$ & $\mathbf{5 . 4} \%$ \\
$2006-2008$ & $16.9 \%$ & $\mathbf{1 3 . 2} \%$ \\
$2008-2013$ & $40.3 \%$ & $\mathbf{3 2 . 5} \%$ \\
\hline
\end{tabular}

Source: authors' own compilation 
Table 2. Electoral innovation, 1953-2018

\begin{tabular}{|c|c|c|c|}
\hline Election & $\begin{array}{l}\text { Number of } \\
\text { new parties }\end{array}$ & $\begin{array}{l}\text { New parties } \\
\text { overall vote }\end{array}$ & \\
\hline 1953 & 0 & $0 \%$ & \\
\hline 1958 & 1 & $2.6 \%$ & Partito Monarchico Popolare (2.63\%) \\
\hline 1963 & 0 & $0 \%$ & \\
\hline 1968 & 1 & $4.5 \%$ & Partito Socialista di Unità Proletaria (4.45\%) \\
\hline 1972 & 0 & $0 \%$ & \\
\hline 1976 & 2 & $2.6 \%$ & Partito Radicale (1.07\%), Democrazia Proletaria (1.52\%) \\
\hline 1979 & 1 & $1.4 \%$ & Partito di Unità Proletaria per il Comunismo (1.37\%) \\
\hline 1983 & 1 & $1.4 \%$ & Partito Nazionale dei Pensionati (1.36\%) \\
\hline 1987 & 1 & $2.5 \%$ & Lista Verdi (2.51\%) \\
\hline 1992 & 3 & $16.1 \%$ & $\begin{array}{l}\text { Rifondazione Comunista (5.62\%), Movimento per la Democrazia - La Rete } \\
\text { (1.86\%), Lega Nord ( } 8.65 \%)\end{array}$ \\
\hline 1994 & 3 & $26.9 \%$ & Forza Italia (21.01\%), Alleanza Democratica (1.18\%), Patto Segni (4.68\%) \\
\hline 1996 & 1 & $4.3 \%$ & Rinnovamento Italiano (4.34\%) \\
\hline 2001 & 3 & $8.0 \%$ & $\begin{array}{l}\text { Italia dei Valori (3.89\%), Democrazia Europea (2.39\%), Partito dei Comunisti } \\
\text { Italiani (1.67\%) }\end{array}$ \\
\hline 2006 & 1 & $1.4 \%$ & Popolari UDEUR (1.40\%) \\
\hline 2008 & 2 & $3.6 \%$ & La Destra - Fiamma Tricolore (2.43\%), Movimento per l'Autonomia (1.13\%) \\
\hline 2013 & 5 & $40.1 \%$ & $\begin{array}{l}\text { Sinistra Ecologia Libertà (3.20\%), Fratelli d'Italia (1.96\%), Scelta Civica (8.30\%), } \\
\text { Movimento Cinque Stelle (25.56\%), Fare per Fermare il Declino (1.12\%) }\end{array}$ \\
\hline 2018 & 3 & $7.1 \%$ & +Europa (2.56\%), Liberi e Uguali (3.39\%), Potere al Popolo (1.10\%) \\
\hline
\end{tabular}

Source: authors' own compilation 
Table 3. Party and bloc parliamentary volatility, 1953-2018

Electoral cycle (T1-T2)

Party volatility at $\mathrm{T2}$

Bloc volatility at $\mathrm{T}_{2}$

\begin{tabular}{lll}
$1948-1953$ & $14.0 \%$ & $\mathrm{n} / \mathrm{a}$ \\
$1953-1958$ & $6.6 \%$ & $\mathrm{n} / \mathrm{a}$ \\
$1958-1963$ & $8.0 \%$ & $\mathrm{n} / \mathrm{a}$ \\
$1963-1968$ & $6.8 \%$ & $\mathrm{n} / \mathrm{a}$ \\
$1968-1972$ & $6.8 \%$ & $\mathrm{n} / \mathrm{a}$ \\
$1972-1976$ & $8.9 \%$ & $\mathrm{n} / \mathrm{a}$ \\
$1976-1979$ & $6.0 \%$ & $\mathrm{n} / \mathrm{a}$ \\
$1979-1983$ & $8.4 \%$ & $\mathrm{n} / \mathrm{a}$ \\
$1983-1987$ & $7.4 \%$ & $\mathrm{n} / \mathrm{a}$ \\
$1987-1992$ & $18.5 \%$ & $\mathrm{n} / \mathrm{a}$ \\
$1992-1994$ & $46.0 \%$ & $\mathrm{n} / \mathrm{a}$ \\
$1994-1996$ & $21.7 \%$ & $\mathbf{2 6 . 4} \%$ \\
$1996-2001$ & $23.1 \%$ & $\mathbf{1 1 . 4} \%$ \\
$2001-2006$ & $13.8 \%$ & $\mathbf{1 4 . 4 \%}$ \\
$2006-2008$ & $24.5 \%$ & $\mathbf{1 6 . 2} \%$ \\
$2008-2013$ & $44.8 \%$ & $35.2 \%$ \\
$2013-2018$ & $42.9 \%$ & $\mathbf{4 2 . 9 \%}$ \\
\hline
\end{tabular}

Source: authors' own compilation 
Table 4. Parliamentary innovation, 1953-2018

\begin{tabular}{|c|c|c|c|c|}
\hline Election & $\begin{array}{c}\text { Number of new } \\
\text { parties in } \\
\text { Parliament }\end{array}$ & $\begin{array}{l}\mathrm{N} \text { seats assigned } \\
\text { to new parties }\end{array}$ & $\begin{array}{l}\% \text { seats assigned } \\
\text { to new parties }\end{array}$ & \\
\hline 1953 & 0 & 0 & $0 \%$ & \\
\hline 1958 & 1 & 14 & $2.4 \%$ & Partito Monarchico Popolare (14) \\
\hline 1963 & 0 & 0 & $0 \%$ & \\
\hline 1968 & 1 & 23 & $3.7 \%$ & Partito Socialista di Unità Proletaria (23) \\
\hline 1972 & 0 & 0 & $0 \%$ & \\
\hline 1976 & 2 & 10 & $1.6 \%$ & Partito Radicale (4), Democrazia Proletaria (6) \\
\hline 1979 & 1 & 6 & $1.0 \%$ & Partito di Unità Proletaria per il Comunismo (6) \\
\hline 1983 & 0 & 0 & $0 \%$ & \\
\hline 1987 & 1 & 13 & $2.1 \%$ & Lista Verdi (13) \\
\hline 1992 & 3 & 102 & $16.2 \%$ & $\begin{array}{l}\text { Rifondazione Comunista (35), Movimento per la } \\
\text { Demorazia - La Rete (12), Lega Nord (55) }\end{array}$ \\
\hline 1994 & 3 & 163 & $25.9 \%$ & $\begin{array}{l}\text { Forza Italia (132), Alleanza Democratica (18), Patto } \\
\text { Segni (13) }\end{array}$ \\
\hline 1996 & 1 & 26 & $4.1 \%$ & Rinnovamento Italiano (26) \\
\hline 2001 & 1 & 10 & $1.6 \%$ & Partito dei Comunisti Italiani (10) \\
\hline 2006 & 1 & 3 & $0.5 \%$ & Popolari UDEUR (3) \\
\hline 2008 & 1 & 8 & $1.3 \%$ & Movimento per l'Autonomia (8) \\
\hline 2013 & 4 & 163 & $26.4 \%$ & $\begin{array}{l}\text { Sinistra Ecologia Libertà (37), Fratelli d'Italia (9), } \\
\text { Scelta Civica (38), Movimento Cinque Stelle (109) }\end{array}$ \\
\hline 2018 & 2 & 16 & $2.6 \%$ & +Europa (2), Liberi e Uguali (14) \\
\hline
\end{tabular}

Source: authors' own compilation 
Table 6. Governmental composition and volatility, 1953-2018

\begin{tabular}{|c|c|c|c|c|c|c|c|c|}
\hline Year & Legislature & Government & $\begin{array}{l}\text { Party of Prime } \\
\text { Minister }\end{array}$ & Cabinet size & $\begin{array}{c}\text { Technocratic } \\
\& \\
\text { independent } \\
\text { ministers }\end{array}$ & $\begin{array}{c}\text { Ministers } \\
\text { from new } \\
\text { parties }\end{array}$ & $\begin{array}{l}\text { Ministers } \\
\text { from } \\
\text { existing } \\
\text { parties }\end{array}$ & $\begin{array}{l}\text { Governmental } \\
\text { volatility }\end{array}$ \\
\hline 1953 & 2 & Pella & $\mathrm{DC}$ & 19 & $0 \%$ & $0 \%$ & $100 \%$ & $0 \%$ \\
\hline 1954 & 2 & Fanfani I & $\mathrm{DC}$ & 19 & $0 \%$ & $0 \%$ & $100 \%$ & $0 \%$ \\
\hline 1954 & 2 & Scelba & DC & 21 & $0 \%$ & $0 \%$ & $100 \%$ & $28.6 \%$ \\
\hline 1955 & 2 & Segni I & DC & 21 & $0 \%$ & $0 \%$ & $100 \%$ & $0 \%$ \\
\hline 1957 & 2 & Zoli & DC & 21 & $0 \%$ & $0 \%$ & $100 \%$ & $28.6 \%$ \\
\hline 1958 & 3 & Fanfani II & $D C$ & 22 & $0 \%$ & $0 \%$ & $100 \%$ & $18.2 \%$ \\
\hline 1959 & 3 & Segni II & DC & 24 & $0 \%$ & $0 \%$ & $100 \%$ & $18.2 \%$ \\
\hline 1960 & 3 & Tambroni & DC & 23 & $0 \%$ & $0 \%$ & $100 \%$ & $0 \%$ \\
\hline 1960 & 3 & Fanfani III & DC & 23 & $0 \%$ & $0 \%$ & $100 \%$ & $0 \%$ \\
\hline 1962 & 3 & Fanfani IV & $\mathrm{DC}$ & 24 & $0 \%$ & $0 \%$ & $100 \%$ & $12.5 \%$ \\
\hline 1963 & 4 & Leone I & $D C$ & 20 & $0 \%$ & $0 \%$ & $100 \%$ & $12.5 \%$ \\
\hline 1963 & 4 & Moro I & DC & 24 & $0 \%$ & $16.7 \%$ & $83.3 \%$ & $37.5 \%$ \\
\hline 1964 & 4 & Moro II & DC & 24 & $0 \%$ & $0 \%$ & $100 \%$ & $4.2 \%$ \\
\hline 1966 & 4 & Moro III & DC & 23 & $0 \%$ & $0 \%$ & $100 \%$ & $8.0 \%$ \\
\hline 1968 & 5 & Leone II & DC & 22 & $0 \%$ & $0 \%$ & $100 \%$ & $34.8 \%$ \\
\hline 1968 & 5 & Rumor I & DC & 25 & $0 \%$ & $0 \%$ & $100 \%$ & $16.0 \%$ \\
\hline 1969 & 5 & Rumor II & DC & 23 & $0 \%$ & $0 \%$ & $100 \%$ & $16.0 \%$ \\
\hline 1970 & 5 & Rumor III & DC & 26 & $0 \%$ & $0 \%$ & $100 \%$ & $34.6 \%$ \\
\hline 1970 & 5 & Colombo & DC & 26 & $0 \%$ & $0 \%$ & $100 \%$ & $3.8 \%$ \\
\hline 1972 & 5 & Andreotti I & $D C$ & 25 & $0 \%$ & $0 \%$ & $100 \%$ & $38.5 \%$ \\
\hline 1972 & 6 & Andreotti II & DC & 27 & $0 \%$ & $0 \%$ & $100 \%$ & $29.6 \%$ \\
\hline 1973 & 6 & Rumor IV & $D C$ & 29 & $0 \%$ & $0 \%$ & $100 \%$ & $27.6 \%$ \\
\hline 1974 & 6 & Rumor V & $\mathrm{DC}$ & 26 & $0 \%$ & $0 \%$ & $100 \%$ & $6.9 \%$ \\
\hline 1974 & 6 & Moro IV & $\mathrm{DC}$ & 25 & $0 \%$ & $0 \%$ & $100 \%$ & $38.5 \%$ \\
\hline 1976 & 6 & Moro V & $D C$ & 22 & $0 \%$ & $0 \%$ & $100 \%$ & $20 \%$ \\
\hline 1976 & 7 & Andreotti III & $D C$ & 21 & $4.8 \%$ & $0 \%$ & $95.2 \%$ & $4.8 \%$ \\
\hline 1978 & 7 & Andreotti IV & DC & 22 & $4.5 \%$ & $0 \%$ & $95.5 \%$ & $0.2 \%$ \\
\hline 1979 & 7 & Andreotti V & $\mathrm{DC}$ & 22 & $0 \%$ & $0 \%$ & $100 \%$ & $22.7 \%$ \\
\hline 1979 & 8 & Cossiga I & $D C$ & 25 & $0 \%$ & $0 \%$ & $100 \%$ & $16.0 \%$ \\
\hline 1980 & 8 & Cossiga II & DC & 27 & $0 \%$ & $0 \%$ & $100 \%$ & $44.4 \%$ \\
\hline 1980 & 8 & Forlani & DC & 27 & $0 \%$ & $0 \%$ & $100 \%$ & $11.1 \%$ \\
\hline 1981 & 8 & Spadolini & PRI & 28 & $0 \%$ & $0 \%$ & $100 \%$ & $5 \cdot 3 \%$ \\
\hline 1982 & 8 & Spadolini II & PRI & 28 & $0 \%$ & $0 \%$ & $100 \%$ & $0 \%$ \\
\hline 1982 & 8 & Fanfani V & DC & 28 & $0 \%$ & $0 \%$ & $100 \%$ & $10.7 \%$ \\
\hline 1983 & 9 & Craxil & PSI & 29 & $0 \%$ & $0 \%$ & $100 \%$ & $12.1 \%$ \\
\hline 1986 & 9 & Craxi II & PSI & 29 & $0 \%$ & $0 \%$ & $100 \%$ & $0 \%$ \\
\hline 1987 & 9 & Fanfani VI & $\mathrm{DC}$ & 26 & $23.1 \%$ & $0 \%$ & $76.9 \%$ & $48.3 \%$ \\
\hline 1987 & 10 & Goria & $D C$ & 30 & $3.3 \%$ & $0 \%$ & $96.7 \%$ & $46.7 \%$ \\
\hline 1988 & 10 & De Mita & DC & 31 & $0 \%$ & $0 \%$ & $100 \%$ & $4.0 \%$ \\
\hline 1989 & 10 & Andreotti VI & DC & 31 & $0 \%$ & $0 \%$ & $100 \%$ & $3.2 \%$ \\
\hline 1991 & 10 & Andreotti VII & $\mathrm{DC}$ & 32 & $0 \%$ & $0 \%$ & $100 \%$ & $10.1 \%$ \\
\hline 1992 & 11 & Amato I & PSI & 26 & $7.7 \%$ & $0 \%$ & $92.3 \%$ & $10.6 \%$ \\
\hline 1993 & 11 & Ciampi & Technocratic & 28 & $32.1 \%$ & $14.3 \%$ & $53.6 \%$ & $38.7 \%$ \\
\hline 1994 & 12 & Berlusconi I & $\mathrm{FI}$ & 26 & $7.7 \%$ & $76.9 \%$ & $15.4 \%$ & $76.9 \%$ \\
\hline
\end{tabular}




\begin{tabular}{|c|c|c|c|c|c|c|c|c|}
\hline 1995 & 12 & Dini & Technocratic & 25 & $100 \%$ & $0 \%$ & $0 \%$ & $92.3 \%$ \\
\hline 1996 & 13 & Prodi I & Ulivo / Indep. & 24 & $20.8 \%$ & $12.5 \%$ & $66.7 \%$ & $79.2 \%$ \\
\hline 1998 & 13 & D'Alema I & DS & 26 & $11.5 \%$ & $7.7 \%$ & $80.8 \%$ & $33.3 \%$ \\
\hline 1999 & 13 & D'Alema II & DS & 27 & $7.4 \%$ & $7.4 \%$ & $85.2 \%$ & $16.2 \%$ \\
\hline 2000 & 13 & Amato II & Technocratic & 25 & $12.0 \%$ & $0 \%$ & $88.0 \%$ & $13.8 \%$ \\
\hline 2001 & 14 & Berlusconi II & $\mathrm{FI}$ & 24 & $12.5 \%$ & $0 \%$ & $87.5 \%$ & $79.7 \%$ \\
\hline 2005 & 14 & Berlusconi III & $\mathrm{FI}$ & 25 & $4.0 \%$ & $0 \%$ & $96.0 \%$ & $19.0 \%$ \\
\hline 2006 & 15 & Prodi II & Ulivo / Indep. & 27 & $14.8 \%$ & $11.1 \%$ & $74.1 \%$ & $82.1 \%$ \\
\hline 2008 & 16 & Berlusconi IV & PDL & 25 & $4.0 \%$ & $0 \%$ & $96.0 \%$ & $94.1 \%$ \\
\hline 2011 & 16 & Monti & Technocratic & 20 & $100 \%$ & $0 \%$ & $0 \%$ & $96.0 \%$ \\
\hline 2013 & 17 & Letta & PD & 22 & $13.6 \%$ & $4.5 \%$ & $81.8 \%$ & $86.4 \%$ \\
\hline 2014 & 17 & Renzi & PD & 17 & $11.8 \%$ & $0 \%$ & $88.2 \%$ & $19.3 \%$ \\
\hline 2016 & 17 & Gentiloni & PD & 19 & $0 \%$ & $0 \%$ & $100 \%$ & $19.5 \%$ \\
\hline 2018 & 18 & Conte & Independent & 19 & $31.6 \%$ & $42.1 \%$ & $26.3 \%$ & $100 \%$ \\
\hline
\end{tabular}

Source: authors' own compilation 
Table 5. Governmental innovation. 1953-2018

\begin{tabular}{|c|c|c|c|}
\hline Year & Government & $\begin{array}{l}\text { Party of Prime } \\
\text { Minister }\end{array}$ & Ministers from new parties \\
\hline 1953 & Pella & $\mathrm{DC}$ & \\
\hline 1954 & Fanfani I & DC & \\
\hline 1954 & Scelba & DC & \\
\hline 1955 & Segni I & DC & \\
\hline 1957 & Zoli & DC & \\
\hline 1958 & Fanfani II & DC & \\
\hline 1959 & Segni II & DC & \\
\hline 1960 & Tambroni & DC & \\
\hline 1960 & Fanfani III & DC & \\
\hline 1962 & Fanfani IV & DC & \\
\hline 1963 & Leone I & $\mathrm{DC}$ & \\
\hline 1963 & Moro I & DC & 4 Antonio Giolitti, Giovanni Pieraccini, Giacomo Mancini, Achille Corona (PSI) \\
\hline 1964 & Moro II & DC & \\
\hline 1966 & Moro III & DC & \\
\hline 1968 & Leone II & $\mathrm{DC}$ & \\
\hline 1968 & Rumor I & DC & \\
\hline 1969 & Rumor II & DC & \\
\hline 1970 & Rumor III & $\mathrm{DC}$ & \\
\hline 1970 & Colombo & $\mathrm{DC}$ & \\
\hline 1972 & Andreotti I & $\mathrm{DC}$ & \\
\hline 1972 & Andreotti II & $\mathrm{DC}$ & \\
\hline 1973 & Rumor IV & $\mathrm{DC}$ & \\
\hline 1974 & Rumor V & $\mathrm{DC}$ & \\
\hline 1974 & Moro IV & $\mathrm{DC}$ & \\
\hline 1976 & Moro V & $\mathrm{DC}$ & \\
\hline 1976 & Andreotti III & $\mathrm{DC}$ & \\
\hline 1978 & Andreotti IV & $\mathrm{DC}$ & \\
\hline 1979 & Andreotti V & $\mathrm{DC}$ & \\
\hline 1979 & Cossiga I & DC & \\
\hline 1980 & Cossiga II & $\mathrm{DC}$ & \\
\hline 1980 & Forlani & $\mathrm{DC}$ & \\
\hline 1981 & Spadolini & PRI & \\
\hline 1982 & Spadolini II & PRI & \\
\hline 1982 & Fanfani V & $\mathrm{DC}$ & \\
\hline 1983 & Craxi I & PSI & \\
\hline 1986 & Craxi II & PSI & \\
\hline 1987 & Fanfani VI & $\mathrm{DC}$ & \\
\hline 1987 & Goria & $\mathrm{DC}$ & \\
\hline 1988 & De Mita & $\mathrm{DC}$ & \\
\hline 1989 & Andreotti VI & $\mathrm{DC}$ & \\
\hline 1991 & Andreotti VII & DC & \\
\hline 1992 & Amato I & PSI & \\
\hline
\end{tabular}




\begin{tabular}{ccccl}
1993 & Ciampi & Technocratic & 4 & Francesco Rutelli (Verdi), Vincenzo Visco, Luigi Berlinguer, Augusto Barbera (PDS) \\
\hline 1994 & Berlusconi I & FI & 20 & Ministers from Forza Italia, Lega Nord, Alleanza Nazionale. \\
1995 & Dini & Technocratic & & \\
\hline 1996 & Prodi I & Ulivo / Indep. & 3 & Lamberto Dini, Augusto Fantozzi, Tiziano Treu (Rinnovamento Italiano) \\
1998 & D'Alema I & DS & 2 & Oliviero Diliberto, Katia Belillo (PdCI) \\
1999 & D'Alema II & DS & 2 & Agazio Loiero, Salvatore Cardinale (UDEUR) \\
2000 & Amato II & Technocratic & & \\
\hline 2001 & Berlusconi II & FI & & \\
2005 & Berlusconi III & FI & & \\
\hline 2006 & Prodi II & Ulivo / Indep. & 3 & Antonio di Pietro (IdV), Paolo Ferrero (PRC), Emma Bonino (RI) \\
\hline 2008 & Berlusconi IV & PDL & & \\
2011 & Monti & Technocratic & & \\
\hline 2013 & Letta & PD & 1 & Enzo Moavero Milanesi (SC) \\
2014 & Renzi & PD & & \\
2016 & Gentiloni & PD & & \\
\hline 2018 & Conte & Independent & 8 & Ministers from M5S \\
\hline
\end{tabular}

Source: authors' own compilation 
Figure 1. Governmental volatility, 1953-2018

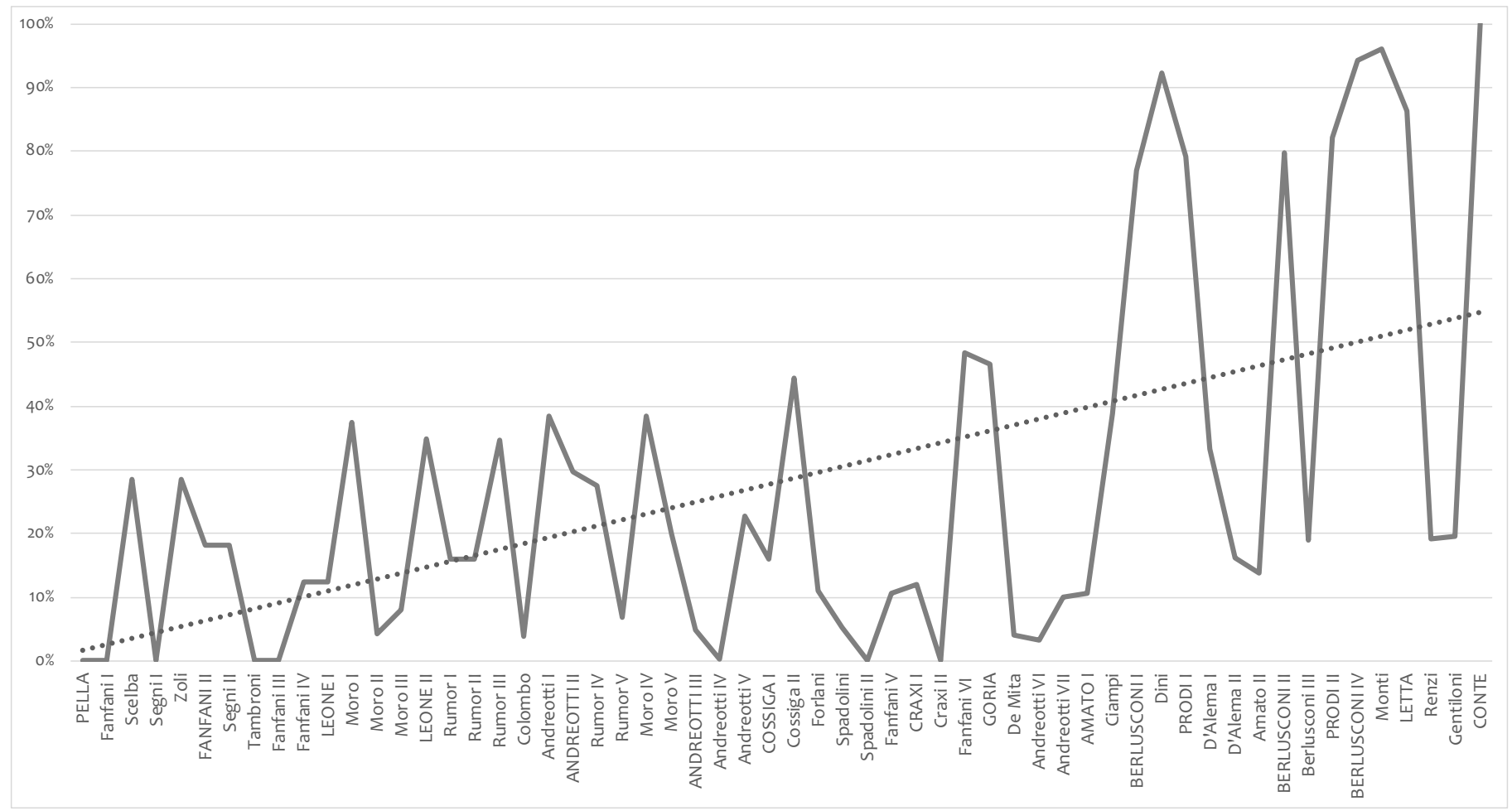

Note: governments reported in capital letters are those formed after new elections. Source: authors' own compilation 
Figure 2. Party system volatility in the three arenas, 1953-2018

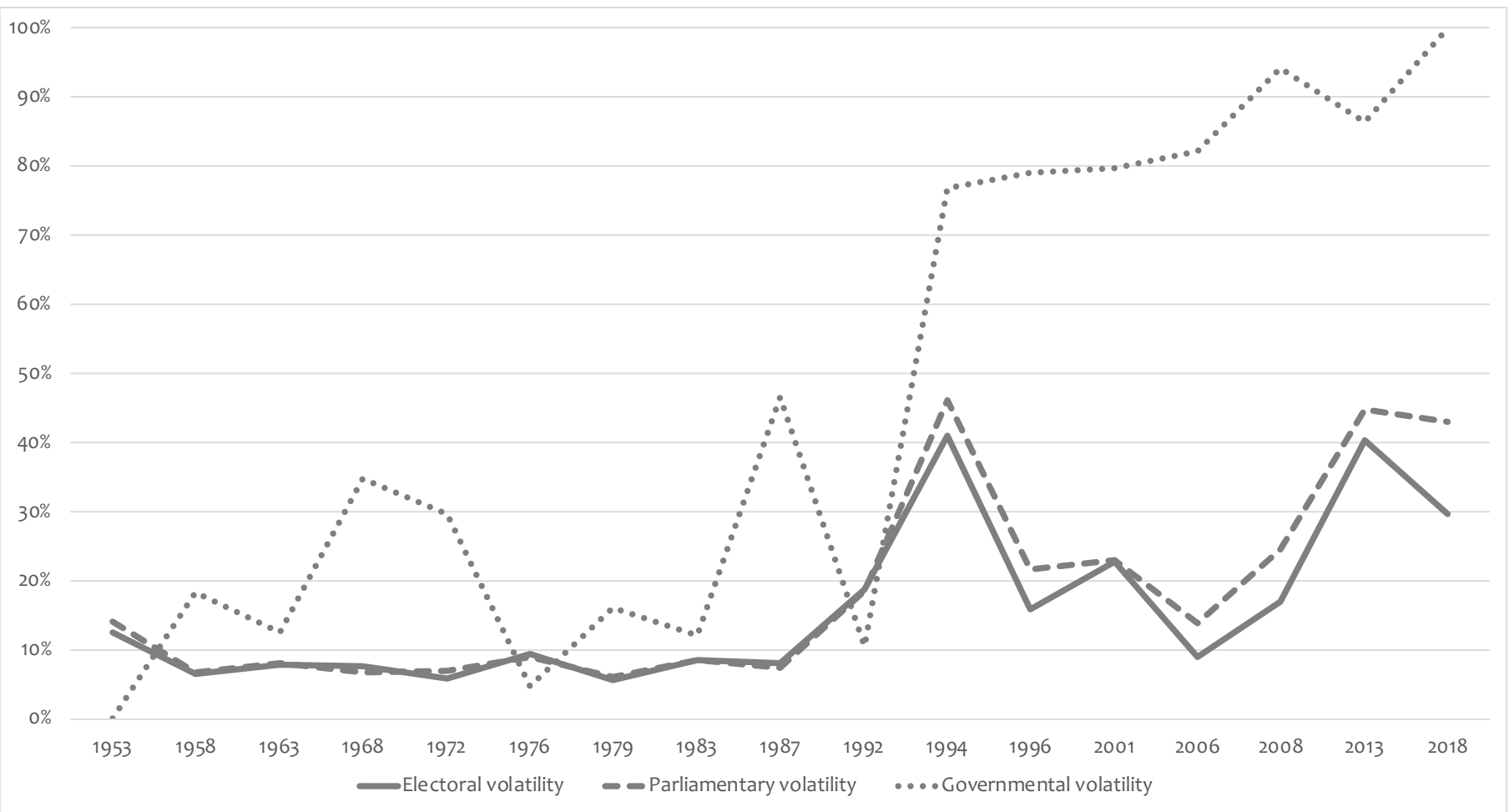

Note: only governments formed after new elections are considered. Source: authors' own compilation 
Figure 3. Party system innovation in the three arenas, 1953-2018

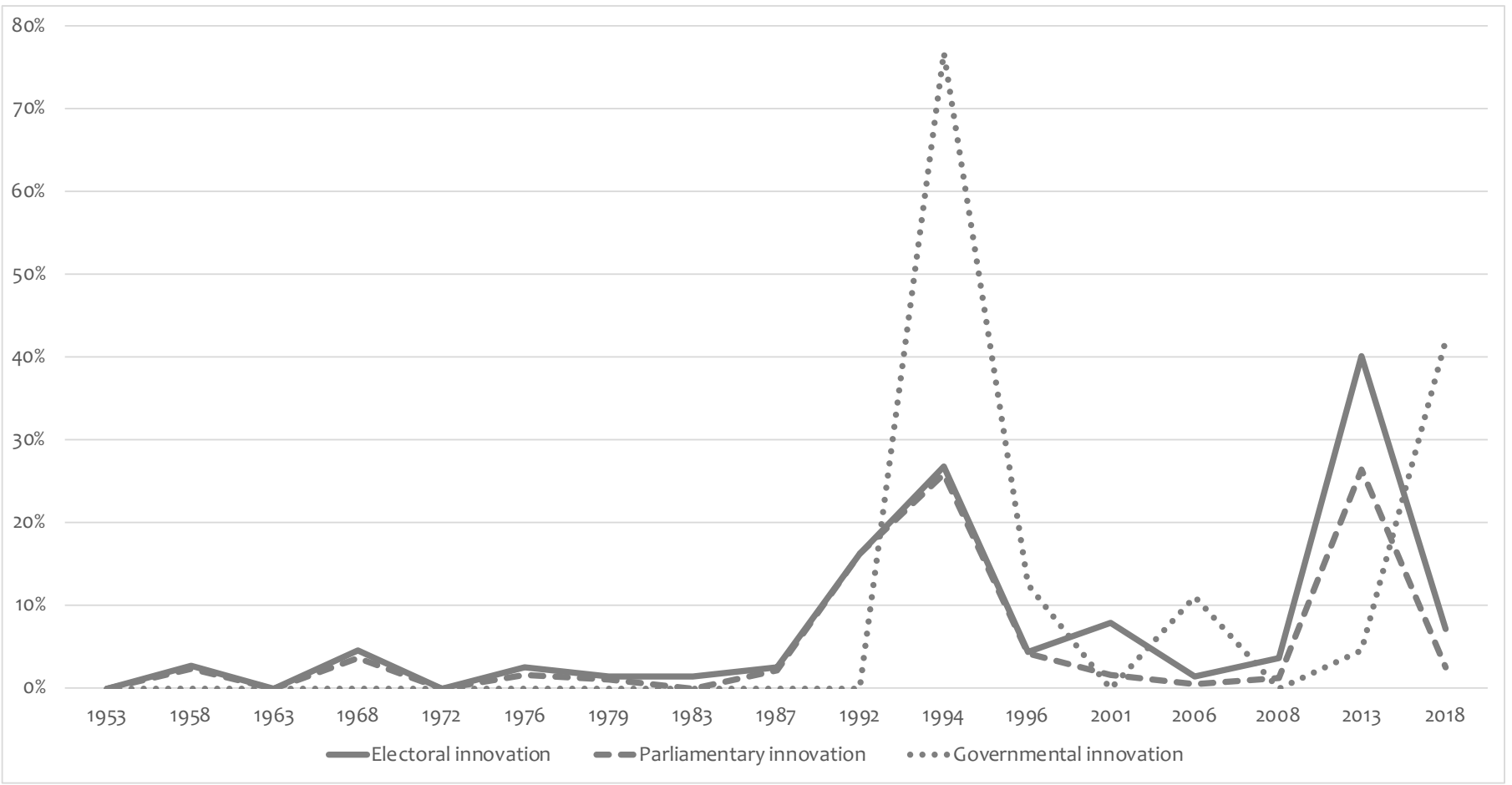

Note: only governments formed after new elections are considered. Source: authors' own compilation 